EPiC Series in Engineering
Volume 3, 2018, Pages 1672-1681
HIC 2018. 13th International
Conference on Hydroinformatics

\title{
Application of hydroinformatic tools for reservoirs discharges rules assessment during a flood event
}

\author{
José Pinho $^{1 *}$, Luís Vieira ${ }^{1}$, José Vieira ${ }^{1}$, Stênio Venâncio ${ }^{2}$, Nuno Simões ${ }^{3}$, \\ José Sá Marques ${ }^{3}$, Fernando Santos ${ }^{3}$ \\ ${ }^{1}$ Centre for Territory, Environment and Construction, Department of Civil Engineering, \\ University of Minho, 4710-057 Braga, Portugal \\ ${ }^{2}$ Department of Civil Engineering, Federal University of Triângulo Mineiro, Brazil \\ ${ }^{3}$ MARE - Marine and Environmental Sciences Centre, Department of Civil Engineering, \\ University of Coimbra, Coimbra 3030-788, Portugal \\ jpinho@civil.uminho.pt
}

\begin{abstract}
Hydrological and hydrodynamic models are valuable tools for understanding complex river hydrodynamics behavior during flood events. These tools have been applied to develop a detailed study of the flood event occurred between 9 and 11 January 2016 in the river Mondego basin, causing severe floods at Coimbra city (Portugal). The study included the characterization of the operational discharge schemes of three upstream dams with direct influence on flow rates in the river basin, and the runoff flows from contributing catchments. A detailed analysis on hydrodynamic water levels at the flooded areas influenced by the operation of a downstream dam and the local river morphodynamics was performed. Hydroinformatic tools were applied in different scenarios allowing the characterization and identification of the key factors responsible for the flood event and contributing to emphasize the need to comply with the established rules for the discharges at the upstream dams during flood events.
\end{abstract}

\section{Introduction}

Flood events usually originate severe social, economic, and environmental impacts. These events can damage property, endangers human lives and are frequently associated to large economic losses. In river basins, intense water runoff often causes soil erosion and concomitant sediment deposition. High rainfall events are not the unique factor that explains those harmful flooding consequences.

\footnotetext{
${ }^{*}$ Corresponding author
} 
Rather, lack or inadequate urban and territorial planning resulting in flood plains occupation by buildings and other infra-structures are responsible for major losses (Adeloye and Rustum, 2011) as well as bad adopted discharges policies at dams during flood events.

Regulations have been established in order to control or mitigate those factors originating flood consequences. EU Floods Directive (EU, 2007) obliges the development of flood hazard maps, which may include information on hydrological and hydrodynamic characteristics of vulnerable regions, i.e. inundated areas, and river flow discharges and water levels.

The considerable progress in computational resources and geographical information processing lead to the development of new hydroinformatics tools useful for supporting and applying new methodologies in river flood management integrating hydrology, hydrodynamics, and environmental databases and models (Penning-Roswell et al., 2000; Pinho et al., 2004; Renner et al., 2009; Werner et al., 2004).

This paper presents a detailed study for a river Mondego flood event focusing on the hydrological and hydrodynamic conditions that leads to inundations nearby the city of Coimbra (Portugal), analysed with the support of different hydroinformatic tools. Flood conditions and inundation factors were analysed for the event that occurred between 9 and 11 January 2016. This analysis was based on the available meteorological and hydrometric information, complemented with results obtained from hydrologic, hydrodynamic and morphodynamic modelling.

\section{Material and Methods}

\subsection{Study Area}

Mondego river basin is a Portuguese basin with an approximate area of $6660 \mathrm{~km}^{2}$. The river extends from Serra da Estrela mountains to the river mouth at Figueira da Foz, in the Atlantic Ocean, along $258 \mathrm{~km}$. The main tributaries are the rivers Alva, Dão and Ceira. In this basin there are several dams whose operation influences the river flow characteristics nearby the city of Coimbra: Aguieira (the greatest storage capacity reservoir); Raiva; Fronhas; and Coimbra. The water stored at Fronhas dam can be transferred to the Aguieira's reservoir. Flows discharged or turbinated to Raiva dam may be pumped to the Agueira reservoir (Figure 1). 


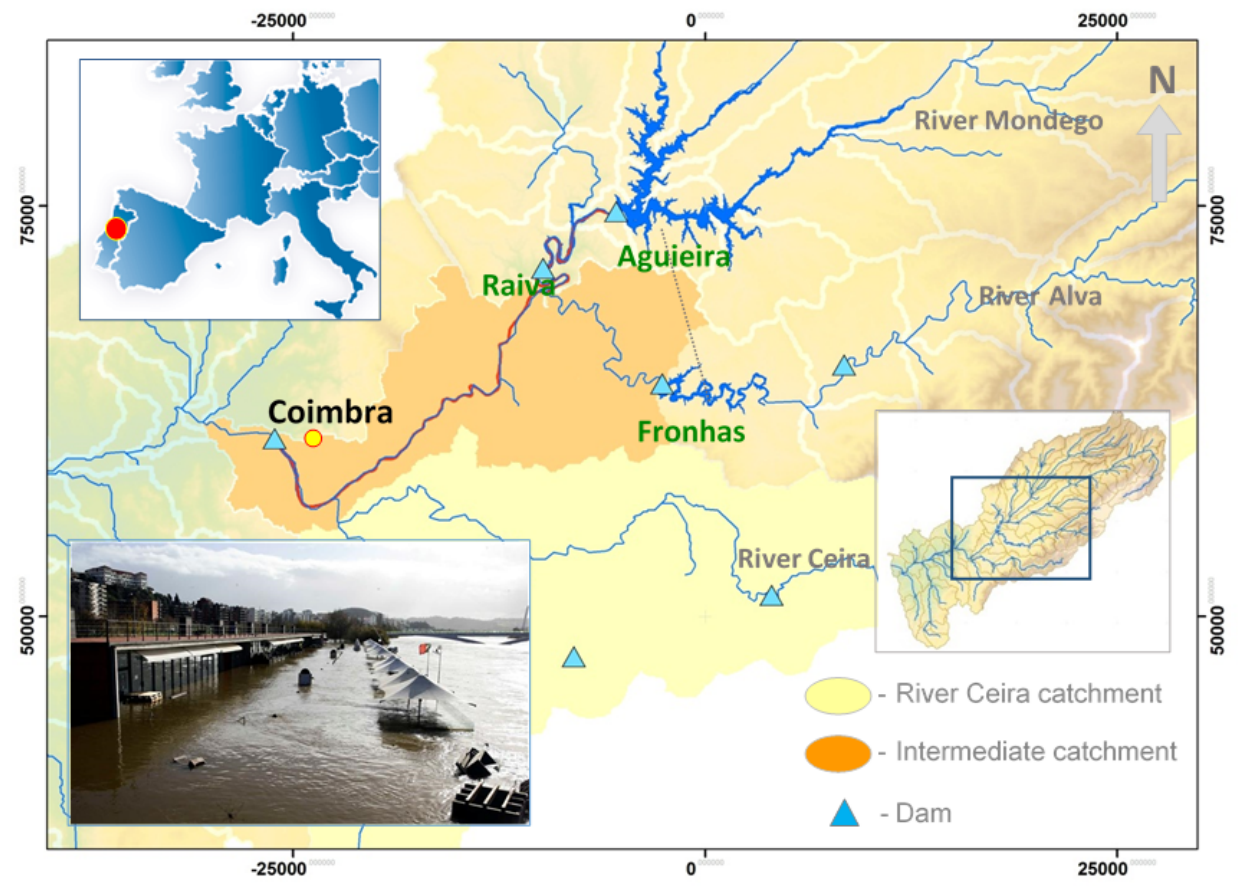

Figure 1: Study site location, river Mondego central river basin; and photo of Coimbra inundation.

Coimbra dam has a small reservoir volume $\left(1,6 \mathrm{hm}^{3}\right.$ for water level at $\left.18,0 \mathrm{~m}-\mathrm{ASL}\right)$ but is responsible for controlling its upstream levels for river discharges up to $930 \mathrm{~m}^{3} / \mathrm{s}$. For higher discharges, according to this infrastructure operational rules, it's floodgates are completely opened. In this scenario river water levels are only conditioned by the cross section contractions caused by the bridge's and mobile gates support pillars and the downstream river section.

The present study focuses on the intermediate stretch of the river Mondego between the main upstream dams and Coimbra city. The upstream dams (Aguieira, Raiva and Fronhas) are also included in the analysis developed in this work.

The river reach under analysis comprises three distinct segments. An initial segment, located downstream Raiva dam, formed by relatively small river cross sections with about $80 \mathrm{~m}$ of surface width and a wider floodplain used for agricultural activities, both located in an embedded valley. In this segment, the longitudinal profile presents a slope of the order of $0.08 \%$, and the river includes several small weirs along its course. The following segment, that presents a cross section with a surface width of about, $200 \mathrm{~m}$ under frequent river discharges, makes the transition between the initial one and the third where the river banks where artificially fixed with river walls. The top of these walls can be inundated along certain locations during flood events.

\subsection{January 2016 flood event}

On $11^{\text {st }}$ January 2016 a severe inundation takes place at Coimbra city affecting several local infrastructures. Rainfall was recorded at seven meteorological stations in the Mondego river basin during the flood event (for the period between 1 and 11 January). Hourly records were obtained from the National Water Resources Information System at the following meteorological stations: Alagoa, Maçainhas, Mangualde, Pombal, Santa Comba Dão, Sátão and Soure. Recorded daily maximum values for the flood event were compared with the historical daily maximums at each station. They 
vary between 29\% (Maçainhas station) and 77\% (Santa Comba Dão station) of the historical maximums. A comparison between accumulated rainfall between 1 and 11 January 2016 and the maximum value of the accumulated values in consecutive periods of 11 days of the historical records was also carried out. In this case the values of the flood event vary from $20 \%$ (Soure station) to $67 \%$ at Alagoa meteorological station of the historical accumulated maximums values.

Hourly hydrometric data were made available by the Portuguese Environment Agency (Fig. 2): water levels immediately upstream and downstream Coimbra dam, at the upstream reservoirs (Aguieira, Raiva, Fronhas) and at Santa Clara Bridge hydrometric station located in the vicinity of the inundated area. Inflows and outflows at all the dams were also made available. Moreover, discharges near the river Ceira mouth and at Coimbra dam were estimated recurring to rating curves available for these locations.

Water level at Aguieira reservoir start rising on January 1, 2016, from 117,89 m elevation until reaching a value of $120,12 \mathrm{~m}$ on January 10 , at midnight, around the beginning of the occurrence of the flood event. During this event a maximum value of $124.66 \mathrm{~m}$ was reached. At Fronhas reservoir there was an increase of water levels from $118.59 \mathrm{~m}$ (01-01-2016 00:00) and a maximum water level of $131.94 \mathrm{~m}$ (12-01-2016 06:00). This variation resulted from the storage of almost all of the reservoir inflows during the initial phase of the period under analysis. During the flood event, part of the volume was transferred to the Aguieira reservoir. At Santa Clara Bridge hydrometric station (located immediately downstream of the bridge) water level reached $19.56 \mathrm{~m}$. It should be noted that this station is located about $1300 \mathrm{~m}$ upstream of Coimbra dam. This way the water surface elevation between these two locations was $1.55 \mathrm{~m}$ at the flood peak time.

Inflow hydrograph at Aguieira reservoir presented a peak of $1777 \mathrm{~m}^{3} / \mathrm{s}(11-01-2016$ 02:00). Other potential flows to this reservoir (transferred from Fronhas reservoir and/or pumped from the Raiva reservoir) are not considered in this inflow maximum value. The maximum discharge at Aguiera dam reached $1118 \mathrm{~m}^{3} / \mathrm{s}$ (11-01-2016 12:00). During the initial phase of the period under analysis the operation of the dam includes turbine and pump periods (records not included in this paper). The maximum discharge at Raiva dam reached a value of $1108 \mathrm{~m}^{3} / \mathrm{s}$ on 11-01-2016 12:00. River Ceira flows (at Ponte Conraria hydrometric station) were estimated based on the rating curve, presenting a maximum value of $255 \mathrm{~m}^{3} / \mathrm{s}$ on 11-01-2016 14:00. At Coimbra dam the estimated peak flow was $1500 \mathrm{~m}^{3} / \mathrm{s}$. This flow, according to information provided by the Portuguese Environment Agency, was estimated based on the original rating curves that were defined before the construction of Coimbra dam. 

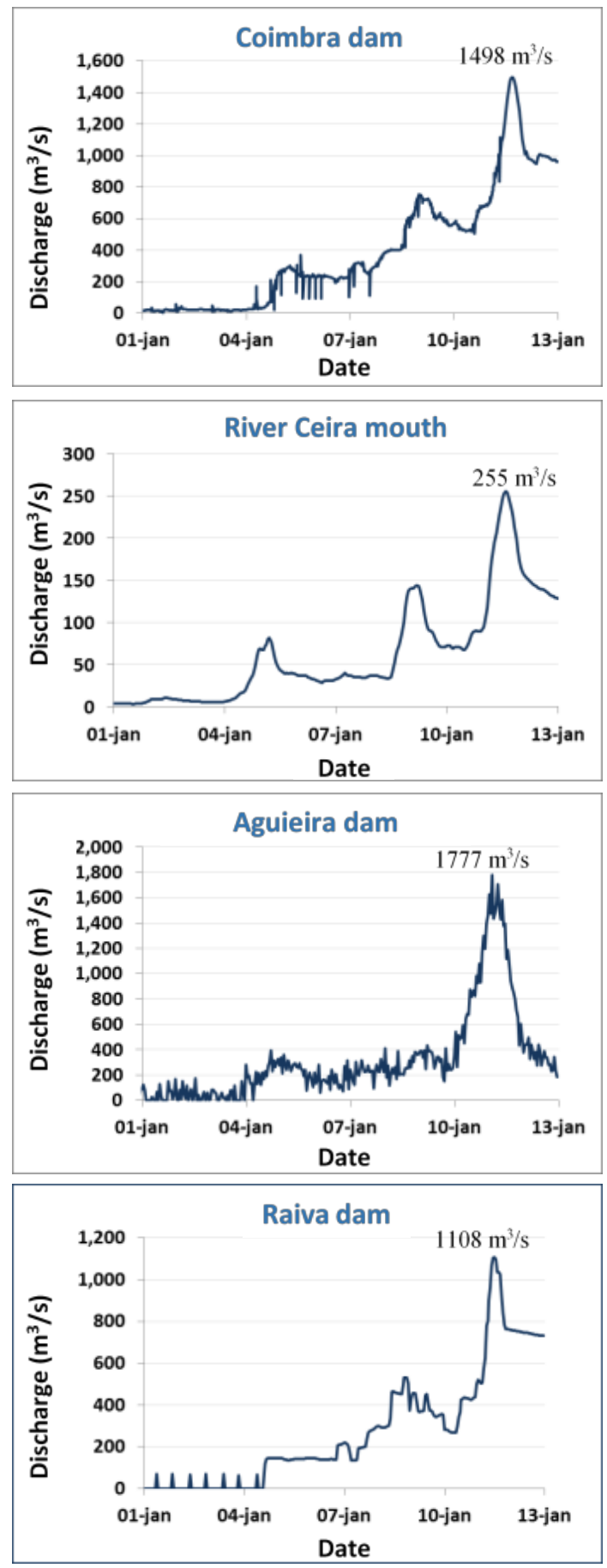
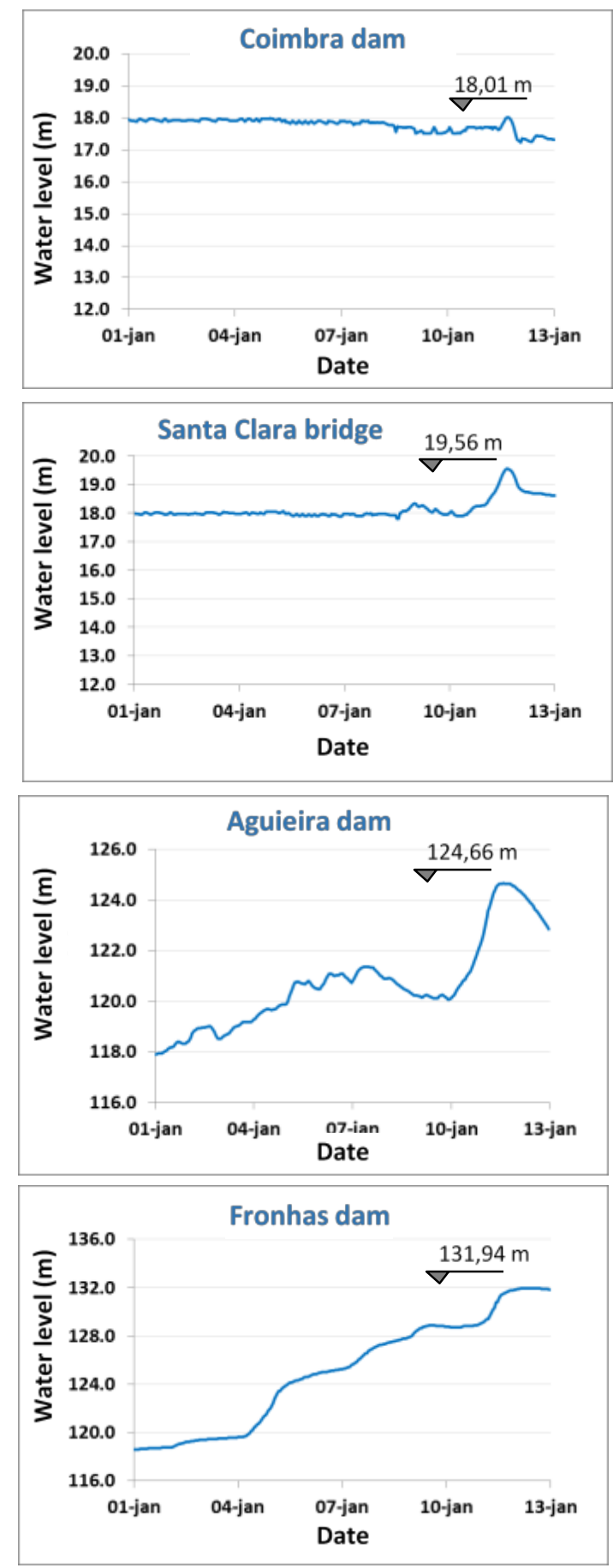

Figure 2: Flood event water levels and discharges measured at dams and hydrometric stations. 


\subsection{Hydrological and hydrodynamic models}

The flood event was analysed recurring to measured hydrological data and hydrodynamic models specifically implemented for this work. The river basin hydrology was simulated by a model based on Sacramento theoretical approach implemented with GIS support. The river hydrodynamics was simulated using the SOBEK software (SOBEK, 2005). In addition, other modelling tools were used namely, RMA2 (ERDC, 2013) and Delft3D (Deltares, 2011). This last two software packages were used in the analysis and verification of specific conditions downstream the city of Coimbra and in the assessment of sediment transport conditions in the inundated fluvial stretch.

Sacramento hydrological model is also implemented in SOBEK software. It allows the quantification of river discharges using precipitation and evapotranspiration data as input (Singh and Wooliser, 2002). The Sacramento model conceptualizes the watershed as a soil column divided vertically into two storage zones which are filled and emptied to simulate infiltration, percolation, baseflow, and interflow through the watershed. The upper and lower zones represent the infiltration capacity of shallow soils and the underlying aquifer, respectively. Runoff is computed as the net excess volume remaining from precipitation after interception and infiltration have been satisfied. Rates of infiltration and soil water volume capacities are represented with conceptual parameters which correspond closely to physical values associated with soil properties such as void space ratio and saturated hydraulic conductivities (Burnash and Ferral, 2002). This model was calibrated for the river Ceira and intermediate sub-basins (Fig. 1) based on the available hydrometric and meteorological stations data. An optimization tool was applied for the estimation of the seventeen required parameters values for each sub-basin.

One and two-dimensional hydrodynamic modelling of rivers is one of the available modules in SOBEK software package. It is based on a robust numerical method that allows obtaining solutions for complex model set-ups. The governing equations are based on the Saint Venant equations and schematized by a finite difference scheme. The spatial discretization of the model was performed using GIS map data of the river basin. It extends from the Raiva and Fronha's dams (upstream boundary) to a section located downstream Coimbra dam (downstream boundary). All the tributaries present in this intermediate reach of river Mondego were considered in this model. Dams discharges flows and river water levels were used, respectively, as upstream and downstream boundary conditions. The model was discretised by 479 calculation points, 12 open boundaries and 27 controlled discharges. To define operational schemes of hydraulic structures it was used the real time control module of SOBEK. The river channel geometry was defined considering 147 cross sections, based on data obtained from bathymetric surveys and Lidar data.

The dams were meticulously modelled in order to integrate all operating hydraulic structures and their characteristics: flood gates, bottom outlets and turbines were modelled through orifice or pump nodes in which all the geometric and hydraulic coefficients were defined. Dams were modelled according to their typology and associated with their controllers in order to simulate their operation procedures. Water levels within the river stretch under analysis depend on the operation of the upstream dams, hydraulic structures and the operation of the Coimbra's dam floodgates, so the real time control module available in SOBEK was crucial to define reliable hydrodynamic scenarios to analyse the inundation conditions.

\section{Results and Discussion}

Prior to the detailed analysis of the operational conditions in which this flood event took place, it was sought to assess the impact that different factors in this complex river system present in terms of water levels and consequently potential inundations at Coimbra city: (i) discharges of upstream Aguieira and Raiva dams; (ii) discharges at upstream Fronhas dam; (iii) river Ceira sub-basin flows; 
(iv) intermediate sub-basin flows; (v) operation of floodgates at Coimbra dam; (vi) uncertainty associated with river discharges measurements at Coimbra; and (vii) sedimentation at the downstream stretch.

The influence of each one of these factors was analysed based on different simulation scenarios. The Mondego river flows discharge at Coimbra city are the result of the contribution of the river Ceira and the intermediate sub-basin and from the upstream dams discharges. The water level variation at Coimbra city was quantified in different scenarios to analyse the effect of factors i) to iv). In each one of these scenarios all the conditions that took place during the flood event were considered with the exception of the one that is being analysed in that scenario (considered with a null contribution). The correspondent variation in terms of water level at Coimbra city was registered and is presented in the first four rows of Table 1. During the flood event all the Coimbra dam floodgates were opened as the river flow discharge increased. This operation is automatically implemented with a PID controller. If any of these gates were maintained closed the effect of this operation (factor v)) would imply an increase of the water level at Coimbra city according to simulated results. Regarding factor vi), simulations were performed considering variations of $100 \mathrm{~m}^{3} / \mathrm{s}$ in the measured discharge at Coimbra dam and the correspondent variation in water levels measured at Santa Clara bridge were registered. For the last analysed factor (vii)) the existing information from two bathymetric surveys spaced by 7 years (2001 and 2008) were used. A simulation was implemented considering the event hydrological conditions but assuming a bathymetric change of the river stretch analogous to the one that occurred in the mentioned period. All the variations of water levels at Santa Clara bridge associated to each one of these factors are presented in Table 1 for the conditions of the flood event.

\begin{tabular}{llc}
\hline \multicolumn{1}{c}{ Inundation factors } & $\begin{array}{c}\text { Water level } \\
\text { variations at } \\
\text { Santa Clara } \\
\text { bridge (m) }\end{array}$ \\
\hline i) & $\begin{array}{l}\text { Absence of upper Aguieira and Raiva dams discharges } \\
\text { ii) }\end{array}$ & $-1,36$ \\
iii) & Absence of upper Fronhas dam discharges & $-0,10$ \\
iv) & Absence of intermediate sub-basin flows discharge & $-0,36$ \\
v) & Operation of gates at Coimbra dam: one gate closed & $-0,12$ \\
vi) & Uncertainty associated with river discharges measurements & $+0,20$ \\
& Coimbra dam & $\pm 0,10$ to 0,20 \\
vii) & Estimated sedimentation occurred in a period of 8 years & $+0,50$ \\
\hline
\end{tabular}

Table 1: Simulated river water levels variations according to different factors affecting inundations at Coimbra city

Obtained results shows that among all the factors analysed in the January 2016 flood event, the factor that had the greatest impact on the river Mondego water level at Coimbra (Santa Clara bridge) was the discharges at Raiva and Aguieira dams.

Several other operational scenarios of the upstream dams were simulated with the calibrated model (upper panel Figure 3). One of those scenarios considered that the water level at Aguieira dam at the beginning of the flood event should be at $117,0 \mathrm{~m}$, as established in the operational rules of this reservoir and that discharges were limited to the maximum capacities of its turbines $\left(450 \mathrm{~m}^{3} / \mathrm{s}\right)$. Obtained results for this scenario are presented in the bottom graph of Figure 3. In this case the water level at Coimbra city would be $18,5 \mathrm{~m}$ (a much lower value in comparison with the maximum registered value of $19,36 \mathrm{~m}$ during the flood event).

The definition of flood warnings and reservoir operational management based solely on monitored hydrometric information does not allow to anticipate flood events with the desired anticipation. Even that the current capacity to forecast inundations for long horizons are highly uncertain the use of these 
technologies considerably increases the capacity to plan operations and this way minimize the impacts of floods.
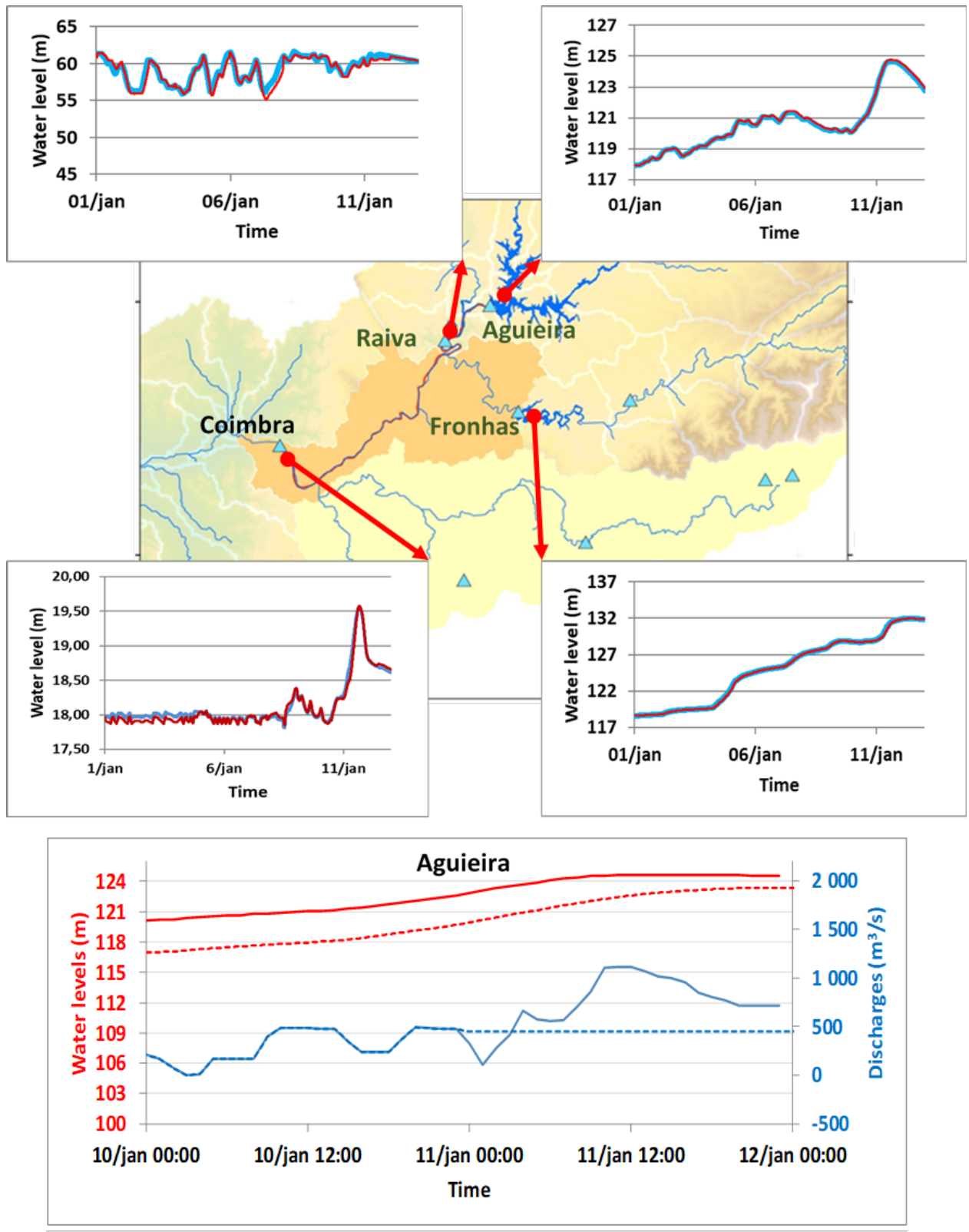

\begin{tabular}{l}
\hline measured discharges $\quad \ldots . . .$. simulated discharges \\
measured water levels $\quad \ldots . . .$. simulated water levels
\end{tabular}

Figure 3: Calibrated model results at measurement stations (upper panel); Aguieira dam operation scheme considering that the water level was $117,0 \mathrm{~m}$ at the beginning of the flood event and the dam discharges were limited to $450 \mathrm{~m}^{3} / \mathrm{s}$ (lower panel). 


\section{Conclusions}

Obtained results showed that the applied hydroinformatic solutions constitute an excellent instrument to analyse a complex system under the influence of different hydraulic structures and natural hydrological processes during a flood event in a river basin.

The key factors for inundations occurred at Coimbra city were analysed recurring to a comprehensive and state of the art set of modelling tools. It was concluded that for the January 2016 flood event, the upstream dam discharges operational schemes were determinant for the water levels verified at that city. Before the beginning of the flood event the reservoir water levels weren't limited to a maximum of $117,0 \mathrm{~m}$ as recommended in the stablished operational rules and this fact was crucial for the difficulties verified in accommodating the inflows to the reservoir during the flood event. In an artificial river system such as the Mondego river basin, operational rules should be clear and preferably monitored through technological platforms that facilitate and integrate relevant information and are shared by all stakeholders in the decision-making process. They should include communication tools with automatic alert generation and preferably based on forecast models.

\section{Acknowledgment}

The authors acknowledge the financial support given by the Portuguese Environmental Agency and the Portuguese National Association of Engineers which contributed to the development of innovative and useful hydroinformatic tools to river flow control in water systems highly dependent of dam discharges.

\section{References}

Adeloye, A., and R. Rustum. (2011). Lagos (Nigeria) flooding and influence of urban planning, Journal of Urban Design and Planning, 164-3; 175-187.

Burnash, R., and Ferral, L. (2002). Conceptualization of the Sacramento Soil Moisture Accounting Model. NWSRFS User Manual Documentation, National Weather Service, NOAA, Silver Spring, MD.

Deltares (2011). Delft3D-Flow User Manual - Simulation of multi-dimensional hydrodynamic flows and transport phenomena, including sediments. Deltares, Netherlands, $64 \mathrm{p}$.

ERDC (2013). ERDC: Engineering Resource Development Center. http://www.erdc.usace.army.mil/ Accessed in May 2017.

EU (2007). Directive of the European Parliament and of the Council 2007/60/EC, establishing a framework for the assessment and management of flood risks, Official Journal 2007 L 288/27, European Commission, Brussels.

M. Renner, M.G.F., Werner, S., Rademacher, Sprokkereef, E. (2009). Verification of ensemble flow forecasts for the River Rhine, Journal of Hydrology, 376, pp 463- 475.

Penning-Roswell, E.C., Tunstall, S.M., Tapsell., Parker, D.J. (2000). The benefits of flood warnings: real but elusive and politically significant, J. Inst. Wat. Environ. Manage., 14, pp 7-14.

Pinho, J.L.S., Vieira, J.M.P., Carmo, J.S.A. (2004). Hydroinformatic environment for coastal waters hydrodynamics and water quality modelling, Advances in Engineering Software; 35, pp 205-222.

Singh, V. P., and Woolhiser, D. A. (2002). "Mathematical Modeling of Watershed Hydrology", Journal of Hydrologic Engineering, 7(4), pp 270-292.

SOBEK (2005). Reference Manual, Delft Hydraulics, Netherlands. 
Werner, M., van Dijk, M., Schellekens, J. (2004). Delft FEWS: An open shell flood forecasting system, in Liong, Phoon and Babovic (Eds.) 6th International Conference on Hydroinformatics, Singapore, pp 1205-1212. 